\title{
Kompetensi Guru Keahlian Ganda Pasca Pelatihan On-In-On-In
}

\author{
Dian Julianto Wahyudi ${ }^{1}$, Purnomo ${ }^{1}$, Yoto $^{1}$ \\ ${ }^{1}$ Pendidikan Kejuruan-Universitas Negeri Malang
}

\section{INFO ARTIKEL}

\section{Riwayat Artikel:}

Diterima: 18-04-2019

Disetujui: 26-06-2019

Kata kunci:
competence;
on-in-on-in training;
multiple skills;
kompetensi;
pelatihan on-in-on-in;
keahlian ganda

keahlian ganda

\author{
Alamat Korespondensi: \\ Dian Julianto Wahyudi \\ Pendidikan Kejuruan \\ Universitas Negeri Malang \\ Jalan Semarang 5 Malang \\ E-mail: djwahyudi1@ gmail.com
}

\begin{abstract}
ABSTRAK
Abstract: The position of vocational productive teachers is very strategic in educating the life of the nation. In 2016, there were still a shortage of vocational productive teachers totaling 91,861 with details of 41,861 in State Vocational Schools and 50,000 in Private Vocational Schools. To fulfill teacher shortages with the addition of productive vocational teachers, the Dual Skills Program was performed. The Dual Skills Program is the addition of assignments and functions of teachers from normative and adaptive teachers plus the task of teaching productive expertise competencies, carried out for 12 months using the On-In-On-In learning model. This study answers how the expertise of multiple teacher competencies after On-In-On-In training in Jombang and Mojokerto. First, pedagogical mastery of dual expertise participants is good. Second, mastery of the skills of dual expertise teachers needs to be added. Third, mastery in making teaching aids for both products and services is quite good. Fourth, mastery in the learning method is quite good, the method used is the lecture method.
\end{abstract}

\begin{abstract}
Abstrak: Posisi guru produktif SMK sangat strategis dalam mencerdaskan kehidupan bangsa. Kondisi di tahun 2016 masih terdapat kekurangan guru produktif SMK sejumlah 91.861 dengan rincian 41.861 di SMK Negeri dan 50.000 di SMK Swasta. Upaya pemenuhan kekurangan guru tersebut dengan penambahan guru produktif SMK melalui Program Keahlian Ganda. Program keahlian ganda merupakan penambahan tugas dan fungsi guru dari guru normatif dan adaptif ditambah tugas mengajar kompetensi keahlian produktif, dilaksanakan selama 12 bulan menggunakan model pembelajaran On-In-On-In. Penelitian ini menjawab bagaimana kompetensi guru keahlian ganda pasca pelatihan On-In-On-In di kabupaten Jombang dan Mojokerto. Pertama, penguasaan pedagogik peserta keahlian ganda baik. Kedua, penguasaan keterampilan guru keahlian ganda perlu ditambah lagi. Ketiga, penguasaan dalam membuat alat peraga baik produk maupun jasa cukup baik. Keempat, penguasaan dalam metode pembelajaran cukup baik, metode yang digunakan adalah metode ceramah plus.
\end{abstract}

Guru didefinisikan sebagai seorang profesional yang memenuhi syarat secara teoritis dan analisis kritis dari fenomena pendidikan dan proses mengajar mata pelajaran yang diampu (Blašková, Blaško, \& Kuchar, 2014). Husein (2017) menjelaskan guru adalah orang yang bertanggung jawab terhadap perkembangan anak didik dengan mengupayakan seluruh potensinya, baik potensi afektif, potensi kognitif, maupun kompetensi psikomotorik. Pasal 1 ayat 1 Undang-undang no.14 tahun 2015 menegaskan guru adalah pendidik profesional dengan tugas utama mendidik, mengajar, membimbing, mengarahkan, melatih, menilai, dan mengevaluasi peserta didik pada pendidikan anak usia dini jalur pendidikan formal, pendidikan dasar, dan pendidikan menengah. Syah (2017) juga menjelaskan guru merupakan tenaga pendidik yang tugas utamanya mengajar, dalam arti mengembangkan ranah cipta, rasa, dan karsa siswa sebagai implementasi konsep ideal mendidik.

Dută \& Rafaila (2014) menjelaskan kompetensi adalah kumpulan yang dinamis dan terpadu dari pengetahuan, keterampilan, nilai, dan sikap. Kompetensi memberikan efisiensi, ketepatan, kepercayaan, dan memungkinkan untuk penyelesaian situasi yang sulit dalam praktik yang dikembangkan. Posisi guru produktif SMK sangat strategis dalam mencerdaskan kehidupan bangsa. Hal ini mengandung makna bahwa ketersediaan jumlah dan kualitas guru produktif yang kompeten akan berdampak sinergis dalam mewujudkan pendidikan SMK yang bermutu. Menurut Harris \& Sass (2011) Meningkatkan kualitas guru adalah kunci dalam meningkatkan pendidikan dasar dan menengah. Disamping itu, kedudukan guru sebagai tenaga profesional berfungsi untuk meningkatkan martabat guru serta perannya sebagai agen pembelajaran untuk meningkatkan mutu pendidikan nasional (Marienda, 2015). Salah satu cara strategis yang perlu dilakukan Pemerintah dalam 
jangka pendek adalah program sertifikasi keahlian dan sertifikasi pendidik bagi guru SMK/SMA yang selanjutnya disebut Program Keahlian Ganda. Dengan program ini, diharapkan jumlah guru produktif SMK di Indonesia dapat terpenuhi. Program keahlian ganda dilaksanakan selama 12 bulan menggunakan model pembelajaran On-In-On-In. Waktu 12 bulan untuk program keahlian ganda ini memunculkan tantangan baru karena waktu yang diperlukan untuk menyelesaikan studi Strata 1 (S-1) untuk menjadi guru produktif SMK sekitar empat tahun atau lebih, sedangkan program ini dilaksanakan selama satu tahun. Hal ini memunculkan pertanyaan terkait ketercapaian kompetensi pasca pelatihan. Penelitian ini menjawab bagaimana kompetensi guru keahlian ganda pasca pelatihan On-In-On-In di kabupaten Jombang dan Mojokerto.

\section{METODE}

Dalam penelitian ini jenis penelitian yang digunakan adalah jenis penelitian studi kasus. Ulfatin (2015) menjelaskan bahwa penelitian dengan menggunakan lebih dari satu kasus, maka istilah yang digunakan adalah Multiple Case Studies. Pada penelitian kualitatif, kehadiran peneliti lebih ditekankan dan peneliti juga dijadikan sebagai instrumen penelitian (Slamet, Yoto, Widiyanti, 2017; Sudjimat, 2015). Dalam penelitian kualitatif peneliti merupakan instrumen kunci (Sugiyono, 2016). Penelitian ini dilaksanakan di SMK Negeri 3 Jombang beralamat di Jalan Pattimura No. 6 Jombang, Jawa Timur dan SMK Negeri 1 Mojokerto yang beralamatkan di Jl. Kedungsari Mojokerto.

Moleong (2016) menjelaskan bahwa sumber data utama dalam penelitian kualitatif merupakan kata-kata dan tindakan dari orang-orang yang diamati atau diwawancarai. Subjek penelitian yang dijadikan informan sumber data, yaitu guru yang telah mengikuti pelatihan On-In-On-In, guru pendamping, wakil kepala sekolah, dan kepala sekolah. Dalam penelitian kualitatif, teknik pengumpulan data yang utama adalah observasi, wawancara, dan studi dokumentasi. Pengumpulan data juga bisa dilakukan dengan gabungan ketiganya atau disebut juga triangulasi (Sugiyono, 2016).

Penelitian ini menggunakan rancangan studi multi kasus, maka dalam menganalisis data dilakukan dua tahap, yaitu (1) analisis data kasus individu (individual case) dan (2) analisis data lintas kasus (cross-case analysis) (Ulfatin, 2015). Teknik pemeriksaan keabsahan data menggunakan tiga kriteria, yaitu (1) kredibilitas (kepercayaaan), (2) konfirmabilitas, dan (3) kebergantungan (Moleong, 2016).

\section{HASIL}

Empat fokus kajian dalam kompetensi guru keahlian ganda pasca pelatihan On-In-On-In, yaitu (1) penguasaan pedagogik, (2) penguasaan kompetensi profesional keahlian ganda, (3) penguasaan dalam membuat alat peraga, dan (4) penguasaan dalam menggunakan metode pembelajaran.

\section{Penguasaan Pedagogik}

Pada fokus pertama tentang penguasaan pedagogik peserta keahlian ganda, di Kabupaten Jombang didapatkan temuan penelitian Penguasaan pedagogik peserta keahlian ganda baik, menguasai, tidak ada masalah. Mereka adalah guru senior dari latar belakang pendidikan sehingga pendamping juga saling belajar dan sharing ilmu, sedangkan di Mojokerto didapatkan temuan penelitian, penguasaan pedagogik peserta keahlian ganda baik, guru senior, sudah sering mengajar sehingga memahami bagaimana memperlakukan anak, melakukan peserta didik itu seperti apa. Pengarahan dulu, kemudian ketika mengajar juga mendampingi anak-anak ketika praktik perlu ditambah strategi-strategi pembelajaran.

\section{Penguasaan Kompetensi Profesional Keahlian Ganda}

Pada fokus kedua tentang penguasaan kompetensi profesional peserta keahlian ganda, di kabupaten Jombang didapatkan temuan penelitian. Penguasaan keterampilan guru keahlian ganda perlu ditambah lagi. Untuk mengajar teori sudah bisa, sedangkan untuk mengajar praktik perlu dilatih lagi. Jika minat belajarnya bagus, senang dengan kompetensi keahlian tersebut tentu kompetensinya tertunjang, pasti bertambah. Di lapangan, guru yang sejak awal mengajar kompetensi keahlian tersebut yang harus menyesuaikan, guru keahlian ganda diberi tugas mengajar sesuai yang diajarkan di program keahlian ganda, sedangkan di Mojokerto didapatkan temuan penelitian bahwa penguasaan keterampilan guru keahlian ganda perlu ditambah lagi. Kompetensi untuk menengah kebawah mungkin cukup, tetapi untuk level advance perlu ditambah lagi.

\section{Penguasaan Dalam Membuat Alat Peraga}

Pada fokus ketiga tentang penguasaan dalam membuat alat peraga, di Kabupaten Jombang didapatkan temuan penelitian. Untuk membuat alat peraga jika berupa produk, guru keahlian ganda dapat membuat produk yang standar. Jika berupa jasa guru keahlian ganda juga dapat mengerjakannya, sedangkan di Mojokerto didapatkan temuan penelitian. Untuk membuat alat peraga jika berupa produk, guru keahlian ganda dapat membuat produk yang standar. Ada pula yang tidak membuat alat peraga, tetapi menggunakan alat peraga. Gambar 1 merupakan alat peraga yang dibuat oleh Guru Keahlian Ganda Kompetensi Keahlian Teknik Audio Video. 


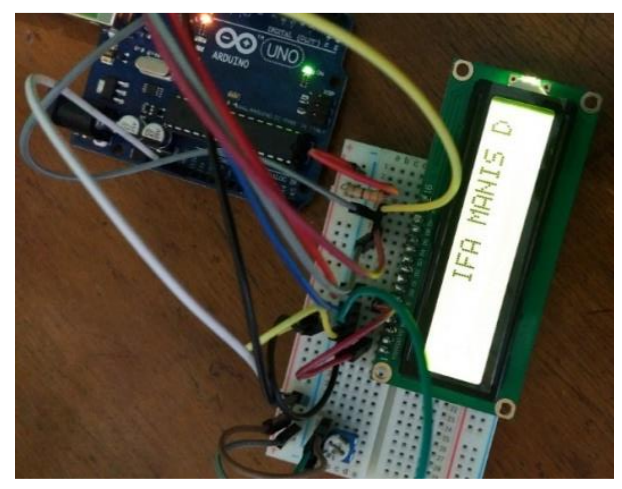

\section{Gambar 1. Running Text Hasil Pengerjaan Peserta KG Kompetensi TAV}

\section{Penguasaan Dalam Metode Pembelajaran}

Pada fokus keempat tentang penguasaan dalam membuat alat peraga, di Kabupaten Jombang didapatkan temuan penelitian. Materi yang diajarkan guru keahlian ganda adalah materi produktif sehingga lebih banyak praktik. Dari hasil observasi metode yang digunakan adalah metode ceramah plus, yaitu metode ceramah plus demonstrasi dan latihan. Sehingga guru menjelaskan materi, memberikan contoh cara mengerjakan tugas, kemudian siswa latihan dan praktik mengerjakan tugas yang diberikan guru, sedangkan di Mojokerto didapatkan temuan penelitian. Terkadang demonstrasi, terkadang observasi, tetapi yang paling sering demonstrasi jadi dijelaskan kemudian anak-anak diberi semacam project, dibimbing untuk pembuatan projectnya. Dari hasil observasi metode yang digunakan adalah metode ceramah plus, yaitu metode ceramah plus demonstrasi dan latihan. Sehingga guru menjelaskan materi, memberikan contoh cara mengerjakan tugas, kemudian siswa latihan dan praktik mengerjakan tugas yang diberikan guru. Perlu ditambah strategi-strategi pembelajaran yang ada di kurikulum 2013.

Dari kedua situs penelitian tersebut terdapat perbedaan dan kesamaan terkait Kompetensi Guru Keahlian Ganda Pasca Pelatihan On-In-On-In. Persamaan dan perbedaan kedua kasus tersebut dijelaskan sebagai berikut. Pertama, pada kasus 1 dan kasus 2, yakni SMKN 3 Jombang dan SMKN 1 Mojokerto memiliki kesamaan penguasaan pedagogik peserta keahlian ganda baik, guru senior, sudah sering mengajar sehingga memahami bagaimana memperlakukan peserta didik itu seperti apa. Pengarahan dulu, kemudian ketika mengajar juga mendampingi anak-anak ketika praktik. Kedua, penguasaan keterampilan guru keahlian ganda perlu ditambah lagi. Untuk mengajar teori sudah bisa, sedangkan untuk mengajar praktik perlu dilatih lagi. Ketiga, untuk membuat alat peraga jika berupa produk, guru keahlian ganda dapat membuat produk yang standar. Jika berupa jasa guru keahlian ganda juga dapat mengerjakannya. Keempat, dari hasil observasi metode yang digunakan adalah metode ceramah plus, yaitu metode ceramah plus demonstrasi dan latihan. Sehingga guru menjelaskan materi, memberikan contoh cara mengerjakan tugas, kemudian siswa latihan dan praktik mengerjakan tugas yang diberikan guru. Kelima, perbedaan kasus 1 yakni, SMKN 3 Jombang di lapangan ketika mengajar, guru yang sejak awal mengajar kompetensi keahlian tersebut yang harus menyesuaikan, guru keahlian ganda diberi tugas mengajar sesuai yang diajarkan di program keahlian ganda. Kasus 2, yakni SMKN 1 Mojokerto kompetensi keahlian seperti jasa boga dan teknik pengolahan hasil pertanian lebih mudah dikuasai daripada kompetensi keahlian yang lain.

Berdasarkan perbandingan kedua kasus serta memerhatikan persamaan dan perbedaan dari kedua kasus tersebut, maka disimpulkan temuan substantif teoritik terkait dengan Kompetensi Guru Keahlian Ganda Pasca Pelatihan On-In-On-In dari kedua lokasi, yakni di SMKN 3 Jombang dan SMKN 1 Mojokerto. Pertama, penguasaan pedagogik peserta keahlian ganda baik, guru senior, sudah sering mengajar sehingga memahami bagaimana memperlakukan peserta didik. Kedua, penguasaan keterampilan guru keahlian ganda perlu ditambah lagi. Untuk mengajar teori sudah bisa, sedangkan untuk mengajar praktik perlu dilatih lagi. Ketiga, penguasaan dalam membuat alat peraga baik produk maupun jasa cukup baik. Keempat, penguasaan dalam metode pembelajaran cukup baik, metode yang digunakan adalah metode ceramah plus, yaitu metode ceramah plus demonstrasi dan latihan.

Dari temuan substantif teoritik terkait dengan Kompetensi Guru Keahlian Ganda Pasca Pelatihan On-In-On-In dari kedua lokasi yakni di SMKN 3 Jombang dan SMKN 1 Mojokerto dapat dibuat diagram sebagaimana ditunjukkan pada gambar 2. 


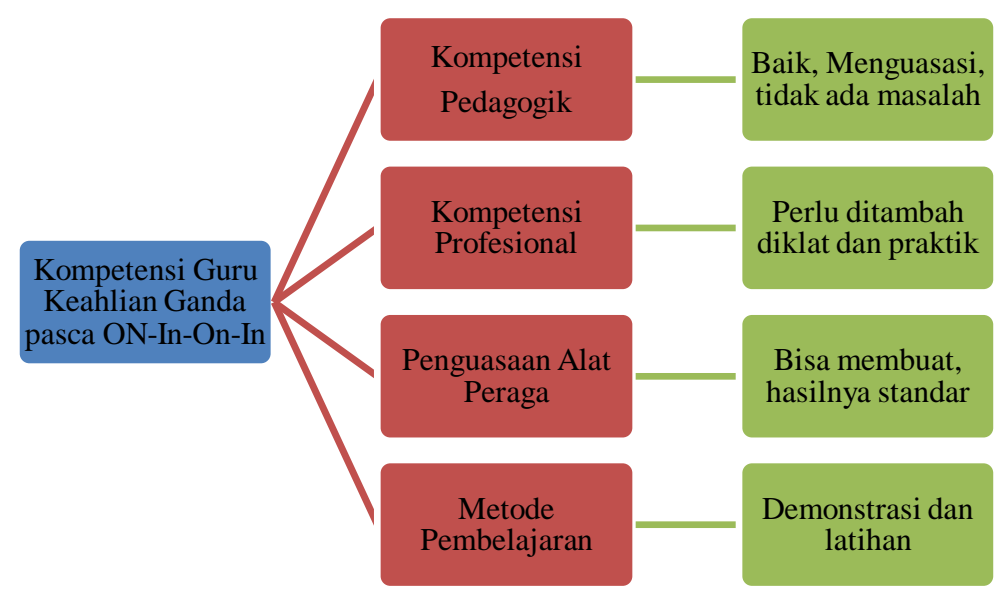

\section{Gambar 2. Kompetensi Guru Keahlian Ganda Pasca Pelatihan On-In-On-In di SMKN 3 Jombang dan SMKN 1 Mojokerto}

\section{PEMBAHASAN}

Empat fokus kajian dalam kompetensi guru keahlian ganda pasca pelatihan On-In-On-In, yaitu (1) penguasaan pedagogik, (2) penguasaan kompetensi profesional keahlian ganda, (3) penguasaan dalam membuat alat peraga, dan (4) penguasaan dalam menggunakan metode pembelajaran.

\section{Penguasaan Pedagogik}

Ondi Saondi (2012) menjelaskan kompetensi pedagogik adalah kemampuan guru dalam mengelola pembelajaran peserta didik yang meliputi pemahaman peserta didik, perancangan dan pelaksanaan pembelajaran, evaluasi hasil belajar dan pengembangan peserta didik untuk mengaktualisasikan berbagai potensi yang dimilikinya. Selain itu, Husein (2017) menjelaskan bahwa kompetensi pedagogik terdiri atas lima sub kompetensi, antara lain (1) memahami peserta didik secara mendalam; (2) merancang pembelajaran, termasuk memahami landasan pendidikan untuk kepentingan pembelajaran; (3) melaksanakan pembelajaran; (4) merancang dan melaksanakan evaluasi pembelajaran; (5) mengembangkan peserta didik untuk mengaktualisasikan berbagai potensinya.

Menurut UU No. 14 Tahun 2005 Guru dan Dosen Pasal 8 Guru wajib memiliki kualifikasi akademik, kompetensi, sertifikat pendidik, sehat jasmani dan rohani, serta memiliki kemampuan untuk mewujudkan tujuan pendidikan nasional. Dalam pasal 10 disebutkan Kompetensi guru sebagaimana dimaksud dalam Pasal 8, meliputi kompetensi pedagogik, kompetensi kepribadian, kompetensi sosial, dan kompetensi profesional yang diperoleh melalui pendidikan profesi. Kompetensi paedagogik merupakan kemampuan mengelola pembelajaran peserta didik. Kompetensi ini dapat dilihat dari kemampuan merencanakan program belajar mengajar, kemampuan melaksanakan interaksi atau mengelola proses belajar mengajar, dan kemampuan melakukan penilaian. Misalnya sebelum mengajar guru membuat rencana pelaksanaan pembelajaran terlebih dahulu yang didalamnya mencakup bagagaimana proses belajar mengajar nantinya akan dilaksanakan sehingga guru tidak akan bingung dalam mengelola kelas dan memberikan penilaian.

Berdasarkan penelitian yang telah dilakukan pada SMKN 3 Jombang dan SMKN 1 Mojokerto penguasaan pedagogik peserta keahlian ganda tergolong baik, guru senior sudah sering mengajar sehingga memahami bagaimana memperlakukan peserta didik. Menurut Nousiainen, Kangas, Rikala, \& Vesisenaho (2018), pengembangan pedagogik guru dengan pendidikan dan pelatihan guru dalam jabatan akan meningkatkan kemampuan profesional dan keterampilan guru. Studi empiris telah menunjukkan pentingnya kompetensi profesional guru, dan lebih khusus tentang kompetensi pedagogis mereka, untuk kualitas pendidikan dan hasil belajar siswa (Evens, Elen, Larmuseau, \& Depaepe, 2018).

\section{Penguasaan Kompetensi Profesional Keahlian Ganda}

Uno (2014) menjelaskan kompetensi profesional seorang guru adalah seperangkat kemampuan yang harus dimiliki oleh seorang guru agar dapat melaksanakan tugas mengajar dengan berhasil. Menurut Ondi Saondi (2012), kompetensi profesional merupakan kemampuan guru dalam menguasai materi pelajaran secara luas dan mendalam yang memungkinkan mereka membimbing peserta didik dalam menguasai materi yang diajarkan. Selanjutnya, Wahyudi (2012) menegaskan kompetensi profesional merupakan kemampuan dalam penguasaan materi pembelajaran secara luas dan mendalam yang 
memungkinkan membimbing peserta didik memenuhi standar kompetensi. Kompetensi profesional guru merupakan kompetensi yang menggambarkan kemampuan khusus yang sadar dan terarah kepada tujuan-tujuan tertentu.

Guru profesional adalah guru yang memiliki kompetensi yang dipersyaratkan untuk melakukan tugas pendidikan dan pengajaran. Kompetensi di sini meliputi pengatahuan, sikap, dan keterampilan profesional, baik yang bersifat pribadi, sosial, maupun akademis. Kompetensi profesional merupakan salah satu kemampuan dasar yang harus dimiliki seseorang guru. Dengan kata lain, pengertian guru profesional adalah orang yang punya kemampuan dan keahlian khusus dalam bidang keguruan sehingga ia mampu melakukan tugas dan fungsinya sebagai guru. Guru profesional adalah orang yang terdidik dan terlatih serta punya pengalaman bidang keguruan. Seorang guru profesional dituntut dengan sejumlah persyaratan minimal memiliki kualifikasi pendidikan profesi yang memadai, memiliki kompetensi kemampuan berkomunikasi dengan siswanya, mempunyai jiwa kreatif dan produktif, mempunyai etos kerja dan komitmen tinggi terhadap profesinya dan selalu melakukan pengembangan diri secara terus-menerus (continous improvement) melalui organisasi profesi, buku, seminar, dan semacamnya.

Kompetensi profesional adalah kompetensi atau kemampuan yang berhubungan dengan penyelesaian tugas-tugas keguruuan. Kompetensi ini merupakan hal yang sangat penting, sebab langsung berhubungan dengan kinerja yang ditampilkan. Berdasarkan penelitian yang telah dilakukan pada SMKN 3 Jombang dan SMKN 1 Mojokerto penguasaan keterampilan guru keahlian ganda perlu ditambah lagi. Untuk mengajar teori sudah bisa, sedangkan untuk mengajar praktik perlu dilatih lagi. Kompetensi guru sangat berpengaruh terhadap kompetensi siswa (Dolezalova, 2015), senada dengan pernyataan tersebut penelitian yang dilakukan Prasertcharoensuk, Somprach, \& Keow (2015) kompetensi guru dan kecakapan hidup siswa berpengaruh signifikan terhadap prestasi belajar siswa.

\section{Penguasaan dalam Membuat Alat Peraga}

Menurut Saud (2017) Kompetensi dipandang sebagai pilar dari suatu profesi. Menguasai dalam pembuatan alat peraga adalah ciri dari profesionalisme seorang guru. Oleh karena itu, seorang profesional yang kompeten harus dapat menunjukkan karakteristik utamanya, yaitu (1) mampu melakukan pekerjaan tertentu secara rasional. Memiliki visi dan misi yang jelas mengapa melakukan apa yang dilakukan berdasarkan analisis kritis dan pertimbangan logis dalam membuat pilihan dan mengambil keputuan tentang apa yang dikerjakan; (2) menguasai perangkat pengetahuan (teori, konsep, prinsip dan kaidah, hipotesis dan generalisasi, data dan informasi) tentang seluk beluk apa yang menjadi bidang pekerjaan; (3) menguasai perangkat keterampilan (strategi dan taktik, metode dan teknik, prosedur dan mekanisme, sarana dan isntrumen) tentang cara bagaimana dan dengan apa harus melakukan tugas pekerjaan; (4) memahami perangkat persyaratan ambang tentang ketentuan kelayakan normatif minimal kondisi dari proses yang dapat ditoleransikan dan kriteria keberhasilan yang dapat diterima dari apa yang dilakukan; (5) memiliki daya dan citra unggulan dalam melakukan pekerjaannya dengan berusaha mencapai yang sebaik mungkin; (6) memiliki kewenangan yang memancar atas penguasaan perangkat kompetensi yang dalam batas tertentu dapat didemonstrasikan dan teruji sehingga memungkinkan memperoleh pengakuan pihak berwenang.

Berdasarkan penelitian yang telah dilakukan pada SMKN 3 Jombang dan SMKN 1 Mojokerto penguasaan dalam membuat alat peraga baik produk maupun jasa cukup baik. Dalam pembuatan alat peraga peserta senantiasa berkonsultasi pada guru pendamping sehingga penguasaannya dapat terus terpantau dan dapat melakukan perbaikan bila belum sesuai standar. Sesuai dengan penelitian yang dilakukan Risdiani (2013) terdapat peningkatan kompetensi guru dalam penggunakan alat peraga sebelum dilakukan tindakan sebesar 34\% pada siklus I meningkat menjadi 50\% dan pada siklus II sebesar $83 \%$, melampaui indikator yang ditetapkan sebesar $66 \%$.

\section{Penguasaan dalam Metode Pembelajaran}

Metode pembelajaran adalah suatu proses yang sistematis dan teratur yang dilakukan oleh pendidik dalam menyampaikan materi kepada muridnya. Dengan cara ini diharapakan tujuan kegiatan belajar mengajar dapat tercapai. Oleh sebab itu, pendidik tentu perlu untuk mempelajari metode pembelajaran. Cara ini juga dapat membuat murid untuk tidak merasa bosan atau jenuh di dalam kelas. Cukup banyak manfaat menggunakan metode yang sistematis dalam proses belajar mengajar, misalnya waktu belajar efektif dan murid semangat belajar.

Berdasarkan penelitian yang telah dilakukan pada SMKN 3 Jombang dan SMKN 1 Mojokerto penguasaan dalam metode pembelajaran cukup baik, metode yang digunakan adalah metode ceramah plus, yaitu metode ceramah plus demonstrasi dan latihan. Sehingga guru menjelaskan materi, memberikan contoh cara mengerjakan tugas, kemudian siswa latihan dan praktik mengerjakan tugas yang diberikan guru. Hal ini sesuai dengan penelitian yang dilakukan Nasution (2017) adanya hasil belajar siswa yang tinggi dan berkualitas dapat dihasilkan dari proses pembelajaran yang berkualitas. Untuk menghasilkan proses pembelajaran yang berkualitas seorang tenaga pendidik membutuhkan kemampuan dalam menerapkan metode pembelajaran yang sesuai dengan kebutuhan dalam kelas, ketidaksesuaian metode pembelajaran yang diterapkan dapat menurunkan kualitas proses pembelajaran itu sendiri. Dengan demikian, perbaikan dan peningkatan hasil belajar siswa di sekolah dapat dilaksanakan dengan adanya penggunaan metode pembelajaran yang tepat. Selain itu, penelitian ini bertujuan mengetahui dan menganalisis mengenai penggunaan metode pembelajaran dalam peningkatan hasil belajar siswa di sekolah. 


\section{SIMPULAN}

Dari penelitian yang telah dilakukan dapat ditarik kesimpulan tentang Kompetensi Guru Keahlian Ganda Pasca Pelatihan On-In-On-In sebagai berikut. Pertama, penguasaan pedagogik peserta keahlian ganda baik, guru senior, sudah sering mengajar, sehingga memahami bagaimana memperlakukan peserta didik. Kedua, penguasaan kompetensi professional atau keterampilan guru keahlian ganda perlu ditambah lagi. Untuk mengajar teori sudah layak, sedangkan untuk mengajar praktik perlu berlatih lagi. Ketiga, penguasaan dalam membuat alat peraga, baik produk maupun jasa cukup baik. Keempat, penguasaan dalam metode pembelajaran cukup baik, metode yang digunakan adalah metode ceramah plus, yaitu metode ceramah demonstrasi dan latihan. Dengan demikian, guru menjelaskan materi, memberikan contoh cara mengerjakan tugas, kemudian siswa latihan dan praktik mengerjakan tugas yang diberikan guru.

Berdasarkan kesimpulan hasil penelitian yang dipaparkan diatas, agar kompetensi guru Keahlian Ganda lebih baik lagi disarankan hal-hal sebagai berikut. Pertama, kepada kepala sekolah diharapkan dapat mengembangkan dan meningkatkan kompetensi guru yang telah mengikuti pelatihan On-In-On-In dengan melibatkan guru dalam penyusunan bahan ajar, proses belajar mengajar, sesuai kompetensi keahlian yang dipilih saat mengikuti program keahlian ganda, memberikan porsi jam mengajar sesuai kompetensi keahlian yang dipilih saat mengikuti program keahlian ganda, melibatkan guru keahlian ganda dalam proses pendampingan praktik kerja industri siswa untuk meningkatkan pemahaman guru tentang industri, bagi kepala SMK di luar kasus yang diteliti (SMK sejenis/serumpun) hasil penelitian ini dapat digunakan sebagai potret sehingga dapat digunakan sebagai bahan pertimbangan dalam mengambil langkah-langkah terbaik untuk menentukan arah SMK yang dipimpinnya. Kedua, kepada instruktur, diharapkan dapat meningkatkan pelaksanaan pembekalan dan pembimbingan sehingga peserta program keahlian ganda mendapatkan kompetensi yang sesuai. Ketiga, kepada peneliti berikutnya, hasil penelitian ini diharapkan dapat digunakan sebagai bahan referensi dan kajian untuk penelitian sejenis yang lebih luas dan mendalam dimasa yang akan datang. Keempat, kepada pengembangan ilmu pengetahuan khususnya pendidikan kejuruan. Hasil penelitian ini diharapkan dapat dijadikan salah satu kajian perbandingan tentang teori kompetensi guru keahlian ganda pasca pelatihan On-InOn-In. Kelima, kepada Direktorat Jenderal Guru dan Tenaga Kependidikan. Hasil penelitian ini diharapkan dapat digunakan sebagai masukan dalam mengambil langkah-langkah kebijakan untuk meningkatkan program keahlian ganda melalui proses pembenahan On-In-On-In. Misalnya, memfokuskan guru peserta pelatihan hanya pada proses diklat, tugas dan beban mengajar dikurangi selama proses diklat sehingga hasil pelatihan lebih efektif dan tujuan program keahlian ganda untuk memenuhi kekurangan guru produktif tercapai dengan maksimal.

\section{DAFTAR RUJUKAN}

Blašková, M., Blaško, R., \& Kuchar, A. (2014). Competences and Competence Model of University Teachers. Procedia Social and Behavioral Sciences, 159, 457-467. https://doi.org/10.1016/j.sbspro.2014.12.407

Dută, N. \& Rafaila, E. (2014). Science Direct Training the Competences in Higher Education - A Comparative Study on the Development of Relational Competencies of University Teachers. Procedia - Social and Behavioral Sciences, 128, 522526. https://doi.org/10.1016/j.sbspro.2014.03.199

Evens, M., Elen, J., Larmuseau, C., \& Depaepe, F. (2018). Promoting the Development of Teacher Professional Knowledge: Integrating Content and Pedagogy in Teacher Education. Teaching and Teacher Education, 75, 244-258. https://doi.org/10.1016/j.tate.2018.07.001

Harris, D. N., \& Sass, T. R. (2011). Teacher Training, Teacher Quality, and Student Achievement. Journal of Public Economics, 95(7-8), 798-812. https://doi.org/10.1016/j.jpubeco.2010.11.009

Husein, L. (2017). Profesi Keguruan Menjadi Guru Profesional. Yogyakarta: Pustaka Baru Press.

Marienda, W., Zainuddin, M., \& Hidayat, E. N. (2015). Kompetensi dan Profesionalisme Guru Pendidikan Anak Usia Dini. Prosiding Penelitian dan Pengabdian Kepada Masyarakat, 6(2), 147-156.

Moleong, L. J. (2016). Metode Penelitian Kualitatif Edisi Revisi. Bandung: Rosdakarya.

Nasution, M. K. (2018). Penggunaan Metode Pembelajaran Dalam Peningkatan Hasil Belajar Siswa. Studia Didaktika, 11(01), 9-16.

Nousiainen, T., Kangas, M., Rikala, J., \& Vesisenaho, M. (2018). Teacher Competencies in Game-Based Pedagogy. Teaching and Teacher Education, 74, 85-97. https://doi.org/10.1016/j.tate.2018.04.012

Ondi, S. A. S. (2012). Etika Profesi Keguruan. Bandung: PT. Refika Aditama.

Prasertcharoensuk, T., Somprach, K., \& Keow, T. (2015). Influence of Teacher Competency Factors and Students' Life Skills on Learning Achievement. Procedia - Social and Behavioral Sciences, 186, 566-572. https://doi.org/10.1016/j.sbspro.2015.04.021

Risdiani. (2013). Peningkatan Kompetensi Guru dalam Penggunaan Alat Peraga Pembelajaran PAI melalui In House Training di SD Muhammadiyah 01 Wuled Kecamatan Tirto Kabupaten Pekalongan Tahun Pelajaran 2012/2013. Tesis tidak diterbitkan. IAIN Walisongo Semarang, Semarang.

Saud, U. S. (2017). Pengembangan Profesi Guru. Bandung: Alfabeta. 
Slamet, M. A., Yoto., \& Widiyanti. (2017). Studi Pengelolaan Kelas Honda pada Program Keahlian Teknik Sepeda Motor di SMK Negeri 9 Malang. Jurnal Pendidikan Profesional, 6(2), 236-243.

Sudjimat, D. A. (2015). Pengantar Metodologi Penelitian. Malang: UM Press.

Sugiyono. (2016). Memahami Penelitian Kualitatif. Bandung: Alfabeta.

Syah, M. (2017). Psikologi Pendidikan. Bandung: PT. Remaja Rosdakarya.

Ulfatin, N. (2015). Metode Penelitian Kualitatif di Bidang Pendidikan: Teori dan Aplikasinya (3rd ed.). Malang: Media Nusa Creative.

Uno, H. B. (2014). Profesi Kependidikan: Problema, Solusi, dan Reformasi Pendidikan di Indonesia. Jakarta: PT. Bumi Aksara.

Wahyudi, I. (2012). Mengejar Profesionalisme Guru: Strategi Praktis Mewujudkan Citra Guru Profesional. Jakarta: Prestasi Pustaka. 